\title{
KEDISIPLINAN GURU BAHASA INGGRIS MASUK KELAS DALAM RANGKA KEGIATAN BELAJAR MENGAJAR SMPN 6 KETAPANG
}

\author{
Aklan \\ Kepala SMP Negeri 6 Ketapang \\ Email: aklana911@gmail.com
}

\begin{abstract}
Abstrak
Penelitian ini bertujuan untuk mengetahui kedisiplinan guru bahasa inggris dalam kegiatan beajar mengajar di SMP Negeri 6 Ketapang. Teknik pengumpulan data yang digunakan yaitu observasi, wawancara dan dokumentasi. Hasil penelitian ini menunjukkan bahwa pembinaan guru melalui bimbingaan dan binaan kepala sekolah sangat dibutuhkan guru sebagai wadah dalam membantu guru-guru untuk mendapatkan bermacam-macam informasi dan pengetahuan mengenai proses pembelajaran. kedisiplinan guru di SMP Negeri 6 Ketapang terdapat peningkatan guna memperbaiki proses belajar mengajar sehingga kewajiban dan tanggung jawab seorang guru terpenuhi dan dapat mentransfer ilmu dengan baik kepada peserta didik dengan memberikan contoh keteladan yang baik. Peserta didik akan dipengaruhi cara kedisiplinannya melewati tingkah laku dan perbuatan gurunya maka dari itu kedisiplinan guru sangat penting untuk ditertibkan dan ditingkatkan guna menaati aturan sekolah sehingga bisa memajukan karakter pendidikan.
\end{abstract}

\section{Kata Kunci : Kedisiplinan Guru Bahasa Inggris , Masuk Kelas, Kegiatan Belajar Mengajar}

\section{PENDAHULUAN}

Pendidikan adalah proses yang memberikan lingkungan edukatif agar peserta didik dapat berinteraksi dengan lingkungan untuk mengembangkan kemampuan yang ada pada dirinya. Kemampuan tersebut berupa kemampuan kognitif yakni kemampuan mengasah pengetahuan, kemampuan afektif yakni kemampuan mengasah kepekaan perasaan dan kemampuan psikomotorik adalah keterampilan melakukan sesuatu.

Pada hakikatnya pendidikan adalah kegiatan mendidik, mengajar dan melatih anak sebagai usaha mentransformasikan nilai-nilai yang baik. Dalam melaksanakan hal tersebut pendidikan mengandung berbagai elemen sebagai satu perpaduan. Adapun elemen pendidikan yaitu; dasar dan tujuan pendidikan, pendidik, peserta didik/anak didik, lingkungan, kurikulum/materi pendidikan, metode, lembaga pendidikan, dan evaluasi. Dalam proses pembelajaran banyak hal yang mempengaruhi prestasi belajar, peranan guru sebagai pelaksana perlu meningkatkan profesionalismenya dalam hal kegiatan belajar mengajar di sekolah terutama kedisiplinan dan memberikan motivasi kepada siswa. Dengan kata lain kedisiplinan dan motivasi merupakan salah satu syarat agar prestasi belajar siswa di sekolah menjadi lebih baik. Selain itu kedisiplinan guru juga akan menjadi suatu rangsangan bagi siswa agar lebih disiplin dalam belajar. Seorang guru profesional memiliki keahlian, keterampilan, dan kemampuan sebagaimana filosofi Ki Hajar Dewantara: "Tut wuri handayani, ing ngarso sung tulodo, ing madya mangun karso". Tidak cukup dengan menguasai materi pelajaran akan tetapi mengayomi murid, menjadi contoh atau teladan bagi murid serta selalu mendorong murid untuk lebih baik dan maju.

Kondisi Pembelajaran di SMP Negeri 6 Ketapang terutama kedisiplinan guru memasuki ruang kelas masih sangat rendah. Masih ada guru yang tidak tepat waktu memasuki ruang kelas. Hal ini pasti berpengaruh besar untuk menumbuhkan kedisipilan pada siswa. Keterlambatan guru memasuki ruang kelas mengakibatkan kegiatan belajar mengajar di SMP Negeri 6 Ketapang menjadi sangat tidak efektif. Guru yang terlambat memasuki ruang kelas mengakibatkan proses pembelajaran berlangsung tidak sesuai tahapan. Padahal kita semua menyadari bahwa peran yang lebih besar dari seorang guru adalah keteladanan sesuai 
dengan filosofi bapak Pendidikan Indonesia yaitu : Ki Hajar Dewantara " Tut wuri Handayani, ing ngarso sung tulodo, ing madya mangun karso ".

Menilik hal di atas salah satu faktor utama yang sangat berpengaruh dalam keberhasilan pembelajaran adalah keberadaan guru. Mengingat keberadaan guru dalam proses kegiatan belajar mengajar sangat berpengaruh, maka sudah semestinya kualitas guru harus diperhatikan. Sebagaimana telah dikemukakan di atas, bahwa dalam upaya meningkatkan mutu pendidikan, aspek utama yang ditentukan adalah kualitas guru. Untuk itu, upaya awal yang dilakukan dalam peningkatan mutu pendidikan adalah kualitas guru yang berbentuk disiplin kerja guru dan profesionalisme.

Disiplin kuat yang dimiliki guru, merupakan salah satu hal penting. Guru yang datang tepat waktu dan tidak meninggalkan kelas sebelum pelajaran berakhir adalah salah satu contoh yang dapat membangkitkan motivasi siswa dalam belajar. Tantangan dunia pendidikan pada zaman sekarang ini adalah tantangan bagi guru di dalam berhubungan dengan siswa dalam proses belajar mengajar. Disini guru diharapkan dapat membangkitkan motivasi belajar, hasrat ingin tahu, dan minat yang kuat pada siswanya untuk mengikuti pelajaran di sekolah dan partisipasi aktif di dalamnya. Sebab semakin banyak yang aktif termotivasi untuk belajar maka semakin tinggi prestasi belajar yang diperolehnya. Untuk menjamin terpeliharanya tata tertib dan kelancaran pelaksanaan tugas dalam mencapai tujuan sekolah, maka diperlukan guru yang penuh kesetiaan dan ketaatan pada peraturan yang berlaku dan sadar akan tanggung jawabnya untuk menyelenggarakan tujuan sekolah. Dengan kata lain kedisiplinan para guru sangat diperlukan dalam meningkatkan tujuan sekolah.

Untuk itu, menegakkan disiplin merupakan hal yang sangat penting, sebab dengan kedisiplinan dapat diketahui seberapa besar peraturanperaturan dapat ditaati oleh guru. Dengan kedisiplinan di dalam mengajar guru proses pembelajaran akan terlaksana secara efektif dan efisien. Keberhasilan belajar siswa itu tidak terlepas dari keberhasilan proses belajar mengajar yang kemungkinan besar di pengaruhi oleh kedisiplinan guru. Sekarang ini, guru di sekolah dituntut menjadi seorang panutan yang baik bagi siswanya, atau ia harus dapat memberikan contoh yang baik ketika mengajar sebagai cerminan bagi siswanya bagaimana berperilaku yang baik. Jadi ketika bertindak, siswa selalu berpatokan pada sikap atau perilaku di sekolah, bisa disimpulkan bahwa kedisiplinan dapat memotivasi siswa untuk belajar karena siswa biasanya akan mengikuti perilaku gurunya. Dengan adanya kesadaran diri untuk melaksanakan kedisiplinan di dalam mengajar, maka diharapkan semua kegiatan yang dilaksanakan sehari-hari dapat membuahkan hasil yang baik sesuai dengan tujuan yang telah ditetapkan. Seorang guru biasanya selalu memberikan motivasi kepada peserta didik untuk belajar lebih giat lagi dan meningkatkan prestasi belajar mereka. Prestasi belajar merupakan hal yang di tunjukkan siswa setelah melakukan belajar mengajar. Hal itu ditunjukkan siswa setelah melakukan proses belajar mengajar. Ini biasanya ditunjukkan dengan angka dan nilai sebagai laporan hasil belajar. Banyak sekali faktor yang mempengaruhi prestasi belajar siswa, baik faktor intern maupun ekstern siswa. Jadi selain kedisiplinan guru, prestasi belajar itu dapat ditingkatkan dengan adanya motivasi belajar yang dimiliki oleh siswa. Karena motivasi sangat mendukung sekali dalam peningkatan prestasi belajar.

Dari uraian diatas, kiranya dapat dilihat pentingnya kedisiplinan guru dan motivasi belajar siswa dalam mencapai keberhasilan suatu pembelajaran. Dalam hal ini penulis mengaitkan kedisiplinan guru dan motivasi belajar dalam rangka meningkatkan prestasi belajar. Oleh karena itu penulis tertarik mengangkat masalah ini sehingga tertuang dalam judul makalah "Kedisiplinan guru Bahasa Inggris masuk kelas dalam rangka kegiatan belajar mengajar di SMP Negeri 6 Ketapang".

Menurut E. Mulyasa disiplin berarti ditujukan untuk membantu peserta didik menemukan diri; mengatasi, mencegah timbulnya masalah disiplin, dan berusaha menciptakan situasi yang menyenangkan bagi kegiatan pembelajaran, sehingga mereka mentaati segala peraturan yang telah ditetapkan. Disiplin adalah suatu keadaan tertib, ketika orang-orang yang tergabung dalam suatu sistem, dan tunduk pada peraturan-peraturan yang ada dengan senang hati. Dalam Dictionary of Education yang dikutip E. Mulyasa bahwa discipline (school) adalah the maintenance of conditions conducive to the efficient 
achievement of the school functions. Pada pengertian diatas, disiplin sekolah dapat diartikan sebagai keadaan tertib ketika guru, staf dan karyawan, serta peserta didik yang tergabung dalam sekolah tunduk kepada peraturan yang telah ditetapkan dengan senang hati. Dimanapun lembaga pendidikan pasti disitu ada seorang guru. Dalam dunia pendidikan peran guru di era zaman sekarang ini keberadaannya sangat vital, karena seiring berkembangnya ilmu pengetahuan dan teknologi maka guru dituntut harus mempunyai inovasi-inovasi atau ide-ide baru dalam melaksanakan pembelajaran di sekolah.

Ditinjau dari sudut psikologi, manusia memiliki dua kecendrungan yakni yang cenderung bersikap baik dan cenderung bersikap buruk, cenderung patuh dan tidak patuh, cenderung menurut atau membangkang kecenderungan tersebut dapat berubah sewaktuwaktu tergantung bagaimana pengoptimalannya. Menurut Sofan Amri dalam bukunya bahwa ada dua faktor penyebab timbulnya suatu tingkah laku disiplin yaitu Ahmad Rohani. 2004: (1) Kebijaksanaan aturan itu sendiri; (b) Pandangan seseorang terhadap nilai itu sendiri.

Aturan dibuat untuk dilaksanakan agar tujuan yang diinginkan bisa tercapai. Tidak semua orang setuju dengan aturan yang dibuat. Aturan dianggap baik, maka kita mau melaksanakan aturan yang ada. Sebaliknya, jika aturan yang dibuat dianggap tidak baik, maka kita tidak mau menaati peraturan yang dibuat. Aturan yang tidak memiliki sanksi tegas akan membuat orang tidak mematuhi aturan yang ada. Aturan yang memiliki sanksi tegas akan membuat orang mematuhi aturan itu dengan disiplin.

Kondisi kedisiplinan di SMP Negeri 6 Ketapang dalam hal ketepatan guru memasuki ruang kelas masih belum maksimal, oleh karena itu penulis selaku Kepala Sekolah di SMP Negeri 6 Ketapang menjadikan topik ini sebagaisebuah makalah dengan harapan kedepan akan ada upaya dari semua pihak yaitu Kepala Sekolah, Guru, siswa dan orang tua siswa untuk bersama-sama meningkatkan kedisipilan sehingga guru tidak adalagi yang terlambat memasuki ruang kelas akibat terlambat dalam memulai pembelajaran sehingga pembelajaran menjadi kurang efektif.

Guru yang disiplin dapat diartikan sebagai guru yang menaati aturan yang dibuat oleh sekolah. Sedangkan guru yang tidak disiplin adalah guru yang sering kali melanggar aturan yang dibuat oleh sekolah. Dapat ditarik kesimpulan bahwa kedisiplinan guru adalah sebuah peraturan yang telah dibuat oleh sekolahyang harus dipatuhi oleh seorang guru dalam mengajar agar proses pembelajaran menjadi lebih efektif dan efisien. Adapun kedisiplinan guru dalam mengajar yaitu Bertanggung jawab dalam melaksanakan proses belajar mengajar dan keberhasilan para murid. Tugas dan tanggung jawab guru yaitu sebagai pengajar, pembimbing dan administrator kelas. Sebagai pengajar, guru bertugas merencanakan dan melaksanakan pengajaran sesuai dengan program yang ditentukan. Sebagai pembimbing guru bertugas memberikan bantuan pada siswa dalam pemecahan masalah yang dihadapinya. Sebagai administrator kelas, guru bertugas dan bertanggung jawab dalam ketatalaksanaan pada umumnya. Berpakaian secara tepat sesuai dengan posisinya sebagai seorang guru (Hasbullah Tabrani. 2004).

Dalam segi penampilan, guru harus berpakaian rapi, sopan dan enak dipandang, serta tidak berlebihan. Guru juga harus dapat menampilkan sikap dan menggunakan gaya bahasa yang sesuai dengan lingkungan kelas tempat ia melakukan proses pembelajaran. Setiap guru harus mampu memberi perhatian terhadap penampilan dalam batas yang proporsional. Gunakan pakaian sesuai standar yang ditentukan aturan. Tidak perlu menggunakan aksesori pakaian lebih dari satu. Berpakaian adalah salah satu bentuk latihan disiplin bagi seorang guru dan murid. Saat ini pemerintah Indonesia menetapkan seragam sekolah dan seragam mengajar yang berbeda untuk setiap hari, itulah salah satu bentuk penerapan disiplin dalam kehidupan. Tepat waktu tiba disekolah dan dikelas. Disiplin erat kaitannya dengan pemanfaatan waktu secara efektif dan efisien. Seorang guru harus bisa memanfaatkan waktu sebaik-baiknya, guru yang profesional akan selalu menghargai waktu dan memposisikan waktu sesuai dengan konteks yang dapat diatur oleh dirinya (Sondang P. Siagian. 1995).

\section{PEMBAHASAN PERMASALAHAN Kondisi Geografis SMPN 6 Ketapang}

Dilihat dari letak geografisnya SMPN 6 Ketapang terletak di Jl. Gajah Mada, 
Sukabangun, Kec. Delta Pawan, Kab. Ketapang, Prov. Kalimantan Barat. Sekolah ini terletak di pinggiran kota, namun keberadaannya sangat strategis, yakni; diapit oleh fasilitas umum yang sangat vital yaitu Bandara (Rahadi Oesman) dan Pelabuhan Sukabangun. Karena letaknya strategis inilah, siswa mendapatkan ruang yang cukup memadai untuk mereka belajar dan melakukan kegiatan-kegiatan sekolah yang lain. Ketenangan lingkungan terjaga dengan baik karena pintu masuk kesekolahan hanya dari satu arah. Pagar tembok yang tinggi juga mengurangi gangguan dari pihak luar terhadap sekolah. Dengan akses jalan yang teratur mempermudah akses lalu lintas menuju sekolah. Walaupun letaknya didaerah padat pemukiman dan dekat dengan pusat keramaian seperti pasar dan pertokoan, namun tidak pernah terjadi kemacetan yang menyebabkan keterlambatan siswa, guru, dan karyawan di SMPN 6 Ketapang ini.

Sejarah Singkat SMPN 6 Ketapang merupakan lembaga pendidikan menengah pertama yang diselenggarakan di bawah naungan Kemendikbud. SMPN 6 Ketapang didirikan atas dorongan dan dukungan masyarakat Kab. Ketapang yang mana daya tampung siswa lulusan Sekolah Dasar (SD) sangat banyak, sehingga mendorong masyakarat dan pemerintah untuk mendirikan sekolah SMPN 6 Ketapang. Atas usulan itulah,maka berdirilah SMPN 6 Ketapang sebagai lembaga pendidikan sekolah menengah pertama. Dalam hal pengadaan tenaga guru (pengajar) SMPN 6 Ketapang selalu berusaha untuk mendapatkan guru dari dinas pendidikan Kabupaten Ketapang sehingga memberikan layanan kepada siswa yang semakin maju dan berkembang. Hal inilah yang menjadikan SMPN 6 Ketapang mulai diperhitungkan oleh masyarakat.

\section{Kondisi Kedisiplinan Guru Bahasa Inggris Masuk Kelas Dalam Kegiatan Belajar Mengajar Di SMP Negeri 6 Ketapang}

Kondisi Proses belajar mengajar di SMP Negeri 6 Ketapang setiap pertemuan didapatkan masalah yang terpapar yaitu kurang efektifnya kedisiplinan guru pada saat masuk kelas. Peneliti mewawancarai salah satu guru yaitu guru bahasa inggris yang ada di SMP Negeri 6 Ketapang. Guru bahasa inggris ini termasuklah salah satu guru yang sering datang terlambat dan kurang disiplin dalam proses belajar mengajar.
Ditahapan ini peneliti memberikan bimbingan dan masukan kepada guru bahasa inggris bahwa pentingnya memperbaiki kebiasaan yang kurang baik dalam mengajar hal tersebut akan berdampak buruk kepada hasil belajar peserta didik. Dari hal tersebut masalah ini harus mendapat perhatian yang khusus bagi kepala sekolah atau peneliti dan memberikan penanganan upaya peningkatan kedisiplinan guru dalam kegiatan belajar.

Sebelum dilakukannya bimbingan dan arahan kebiasaan guru datang terlambat kesekolah hampir tiap hari terjadi bukan hanya guru bahasa inggris saja yang memiliki kebiasaan seperti itu tetapi guru lain juga sering melakukan hal seperti itu, akibat dari masalah tersebut terganggunya kegiatan belajar mengajar didalam kelas, peserta didik menjadi rebut didalam kelas suasana belajar harusnya aktif hanya diaktifkan oleh keributan peserta didik yang main-main dikelas, bukan hanya itu kelas yang belajar yang ada gurunya pun merasa terganggu dengan ada nya kelas kosong. Keterlambatan guru hadir berlangsung hingga satu jam pelajaran. Dari hal tersebut peneliti sekaligus kepala sekolah melakukan pembinaan dan bimbingan guna menangani uapaya peningkatan kedisiplinan guru dengan menaati aturan sekolah, setelah dilakukan penanganan dan pembinaan ditekankan harus mengubah kebiasaan yang buruk dan mengurangi jam-jam pelajaran yang kosong serta bertanggungjawab atas matapelajaran yang diampuh.

Dalam keseluruhan proses pendidikan di SMPN 6 Ketapang, pembelajaran merupakan aktivitas yang paling utama. Ini berarti bahwa keberhasilan pencapaian tujuan pendidikan banyak bergantung pada bagaimana proses pembelajaran dapat berlangsung secara efektif. Pemahaman seorang guru terhadap pengertian pembelajaran akan sangat mempengaruhi cara guru itu mengajar.Pembelajaran merupakan proses interaktif melalui pengetahuan dan keterampilan yang dibagi bersama siswa dengan tujuan agar para siswa meningkatkan pemahaman dan hasil belajar. Jadi dapat disimpulkan bahwa pembelajaran pada hakikatnya adalah suatu usaha untuk membuat peserta didik belajar atau suatu kegiatan untuk membelajarkan peserta didik. Pada konteks tersebut, guru sebagai fasilitator harus berupaya menciptakan kondisi agar terjadi kegiatan belajar dan melakukan usaha-usaha yang 
terencana dalam memanipulasi sumber-sumber belajar agar terjadi proses belajar dalam diri peserta didik. Ciri-ciri Pembelajaran diantaranya adalah Merupakan upaya sadar dan disengaja, pembelajaran harus membuat siswa belajar, tujuan harus ditetapkan terlebih dahulu sebelum proses dilaksanakan, pelaksanaannya terkendali, baik isinya, waktu, proses, maupun hasilnya.

\section{Faktor-Faktor Yang Mempengaruhi Kedisiplinan Guru Bahasa Inggris Dalam Kegiatan Belajar Mengajar di SMP Negeri 6 Ketapang}

Setelah dievaluasi ada beberapa faktor yang menghambat kedisiplinan guru yang terlambat masuk kelas dalam proses belajar mengajar yaitu:

1. Faktor Kebijakan Pimpinan Faktor kebijakan pimpinan sangat berpengaruh terhadap kedisiplinan guru sebab kebijakan pimpinan akan menjadi pedoman dan contoh atau panutan bagi para bawahan (guru), mulai dari kehadiran kepala sekolah, kemampuan mengkondisikan bawahan, kemampuan menciptakan suasana kerja yang menyenangkan, ketegasan dalam menjalankan tugasnya, bentuk kepemimpinannya serta tindak lanjut atau sanksi dari kepala sekolah dan sebagainya.

2. Faktor Kurangnya Kesadaran Diri faktor lain yang juga sangat mempengaruhi kedisiplinan guru dalam melaksanakan tugasnya di SMP Negeri 6 Ketapang adalah faktor kurangnya kesadaran diri guru itu sendiri akan tugas dan tanggung jawabnya sebagai guru. Kesadaran diri merupakan proses mengenali motivasi, pilihan, dan kepribadian lalu menyadari pengaruh faktor- faktor tersebut atas penilaian, keputusan, dan interaksi dengan orang lain. Dengan demikian kurangnya kesadaran diri guru di SMP Negeri 6 Ketapang disini adalah guru belum disiplin dalam melaksanakan tugasnya karena kurangnya kesadaran diri akan peraturan sekolah yang bersangkutan serta kurangnya kesadaran akan tugas yang telah diberikan kepadanya.

3. Faktor Jarak Tempat Tinggal dengan Sekolah Jarak tempat tinggal dengan sekolah mempengaruhi kedisiplinan guru dalam melaksanakan tugasnya, karena beberapa alasan yang pertama karena jarak tempat tinggal yang jauh, jalan susah, sulit meninggalkan keluarga, kemudian karena tempat tinggal di tempat mengajar tersebut tidak ada serta butuh pengeluaran yang banyak (biaya mahal).

Dalam sebuah proses pendidikan atau pembelajaran di SMPN 6 Ketapang, guru merupakan salah satu komponen terpenting karena dianggap mampu memahami, mendalami, melaksanakan, dan akhirnya mencapai tujuan pendidikan. Berdasarkan hal tersebut, maka guru menjadi pihak yang sangat mempengaruhi proses pembelajaran di dalam kelas. Pengaruh guru dalam proses pembelajaran di kelas berkaitan erat dengan keprofesionalitasan guru itu sendiri. Guru yang profesional didukung oleh tiga hal, yakni: keahlian, komitmen, dan keterampilan. Selain tiga hal keprofesionalan guru, hal-hal yang akan berpengaruh terhadap proses pembalajaran. Kondisi psikis dan emosional akan sangat mempengaruhi proses pembelajaran di dalam kelas. Apa saja yang menjadi metode pembelajaran dan materi yang akan diajarkan akan menjadi tak maksimal ketika dilakukan dalam proses pembelajaran apabila kondisi kejiwaan guru mengalami masalah. Guru yang terlalu galak, sedang mengalami masalah pribadi, atau pun tidak bisa mengontrol diri, akan menjadi faktor penyebab buruknya pelaksanaan proses pembelajaran. Oleh karena itu, seorang guru haruslah mampu secara profesional mengendalikan dirinya ketika berada pada kondisi psikis dan emosi tertentu yang dapat mengganggu proses pembelajaran di kelas.

Kemampuan mengajar bagi seorang guru sangatlah penting. Sebagai pengajar, seorang guru harus dapat merangsang terjadinya proses berpikir dan dapat membantu tumbuhnya sikap kritis serta mampu mengubah pandangan para muridnya. Kemampuan mengajar menjadi sangat penting untuk dikuasai mengingat proses transfer pengetahuan, sikap, dan keterampilan berlangsung di dalamnya. Tanpa kemampuan mengajar yang baik, proses pembelajaran di kelas tidak akan berlangsung secara maksimal. Guru setidaknya harus menguasai bahan bidang studi dalam kurikulum sekolah termasuk bahan pendalamannya serta kemampuan mengelola program belajar mengajar seperti merumuskan tujuan instruksional, mengenal dan dapat menggunakan metode mengajar serta mampu memilih dan menyusun prosedur instruksional yang tepat. Guru juga dituntut melaksanakan 
program belajar mengajar, mengenal kemampuan peserta didik dan merencanakan serta melaksanakan pengajaran remedial. Kemampuan mengajar guru juga erat kaitannya dengan media yang digunakan. Sebelum era globalisasi dan pesatnya perkembangan teknologi, pengajaran konvensional menggunakan metode ceramah satu arah dengan papan tulis dan kapur lazim digunakan. Namun, di era globalisasi yang menghadirkan banyak media dan sumber belajar, kemampuan mengajar guru juga harus disesuaikan dengan kondisi zaman. Penggunaan media yang disukai dan menarik perhatian peserta didik, juga turut meningkatkan kualitas dalam proses pembelajaran. Namun, dalam menggunakan media pendidikan sebagai alat komunikasi, hendaknya harus didasarkan pada pemilihan yang objektif. Sebab, penggunaan media pendidikan tidak sekadar menampilkan program pengajaran ke dalam kelas, karena harus dikaitkan dengan tujuan pengajaran yang akan dicapai, strategi kegiatan belajar mengajar, dan bahan. Kondisi kelas yang kondusif berkaitan dengan kondisi peserta didik saat proses pembelajaraan sedang dilakukan. Kondisi kelas yang baik menuntut terjadinya interaksi antara guru dan peserta didik dengan baik dan saling menghargai, sehingga penyerapan materi yang disampaikan guru kepada peserta didik dapat berjalan maksimal, yang akan menghasilkan hasil belajar seperti apa yang diharapkan. Kondisi kelas yang kondusif akan mengakomodir pencapaian eksplorasi bakat dan minat peserta didik dengan maksimal pula. Dalam praktiknya, kondisi kelas yang kondusif merupakan salah satu faktor yang mempengaruhi proses pembelajaran di kelas yang harus diusahakan oleh guru

Di dalam kelas, guru melakukan aktivitas mengajar, yang artinya guru mentransfer pengetahuan atau keterampilan dari satu pihak ke pihak lain. Untuk menjaga kekondusifan atau proses pembelajaran di dalam kelas berlangsung secara maksimal dalam hal transfer pengetahuan dan keterampilan, maka kondisi kelas perlu diatur dengan baik oleh guru. Misalnya, mengatur agar peserta didik tidak berbuat halhal yang dapat mengganggu aktivitas pembelajaran di dalam kelas seperti berbuat onar dan menimbulkan suara gaduh, mengganggu peserta didik yang lain, dan sebagainya. Hal lain yang juga harus diperhatikan adalah kondisi peserta didik yang lelah atau pun tidak sepenuhnya berkonsentrasi terhadap apa yang guru ajarkan, maka guru harus mampu mengatasinya. Dalam hal ini, guru harus benarbenar mengetahui kondisi psikis dan emosional masing-masing peserta didik secara mendalam dan mengatasi masalah tersebut dengan kreatif. Dengan hal tersebut, guru akan mudah menyelesaikan masalah peserta didiknya yang kemudian akan berpengaruh bagi terciptanya proses pembelajaran yang maksimal.

Peserta didik sebagai penerima berbagai transfer pengetahuan, sikap, dan keterampilan guna perubahan dalam dirinya sebagai proses pembelajaran juga menjadi penentu dan hal yang mempengaruhi proses pembelajaran itu sendiri. Di antara pengaruh peserta didik dalam proses pembelajaran adalah kondisi peserta didik itu sendiri yang dipengaruhi beragam aspek dari dalam dirinya dan lingkungan sekitarnya yang nantinya akan berdampak pada kesiapannya dalam menerima pelajaran. Sebagai contoh, peserta didik dari latar belakang ekonomi yang lemah, akan mengalami kesulitan dalam hal pemenuhan kebutuhan sekolah seperti buku tulis dan alat tulis sehingga proses pembelajaran yang dilakukannya di dalam kelas menjadi terganggu. Contoh lain, peserta didik yang tidak menerima kasih sayang yang cukup dari keluarganya, maka akan mencari kegiatan lain yang belum tentu baik sehingga akan mempengaruhi sikap dan wataknya ketika proses pembelajaran di dalam kelas. Misalnya ia akan mengganggu teman sekelasnya, melakukan tindak kekerasan, atau hal-hal yang melanggar norma yang berlaku. Hal-hal yang berkaitan dengan kondisi siswa tersebut, akan berdampak luas bagi proses pembelajaran, seperti mempengaruhi peserta didik yang lain dan kondisi kelas. Peserta didik yang ingin mengikuti proses pembelajaran dengan baik, akan terganggu jika ada salah satu peserta didik yang mengganggu jalannya proses pembelajaran. Lingkungan yang mempengaruhi proses pembelajaran di dalam kelas mencakup lingkungan kelas dan lingkungan sekitar sekolah.

Lingkungan kelas merupakan suatu tempat tertentu yang secara spasial menjadi lokasi proses pembelajaran. Kelas tidak hanya memiliki batasan ruang dalam sebuah gedung sekolah, tapi dapat dilakukan di mana saja asalkan terjadi interaksi pembelajaran antara guru dan peserta didik serta merupakan bagian 
dari proses pembelajaran yang sistematis. Lingkungan kelas akan sangat mempengaruhi proses pembelajaran. Hal ini berkaitan dengan kondisi dalam kelas itu sendiri. Misalnya, kondisi kebersihan kelas, sarana dan prasarana, arsitektur, pencahayaan, dan sebagainya. Kondisi kelas yang kotor, jelas akan mengganggu proses pembelajaran dan menimbulkan rasa ketidaknyamanan. Termasuk sarana dan prasarana, arsitektur, dan pencahayaan yang buruk, turut akan memperburuk kualitas proses pembelajaran di kelas. Sarana dan prasarana dalam kelas juga mencakup bagian dari lingkungan kelas. Kelas dengan sarana dan prasarana seperti meja, kursi, papan tulis, dan media pembelajaran yang menarik, akan meningkatkan kualitas proses pembelajaran di kelas.

Lokasi sekolah turut mempengaruhi proses pembelajaran di kelas. Sekolah yang terletak di lingkungan yang sejuk dan asri akan mendukung proses pembelajaran. Berbeda dengan sekolah yang terletak di lingkungan industri yang panas dan penuh polusi atau sekolah yang terletak di lokasi yang kerap kebanjiran. Kondisi tersebut akan membawa dampak buruk bagi proses pembelajaran di kelas.

\section{SIMPULAN DAN SARAN Simpulan}

Berdasarkan hasil pembahasan yang telah disampaikan di atas, dapat disimpulkan sebagai berikut: (1) Kedisiplinan guru bahasa inggris dalam kegiatan belajar mengajar di SMP Negeri 6 Ketapang sudah mulai meningkat dengan upaya pembinaan dari kepala sekolah atau peneliti. Mengingat kedisiplinan itu adalah hal yang paling penting yang ditunjukan oleh guru dalam melaksanakan kewajiban nya hal tersebut akan berdampak bagi hasil belajar peserta didik. Guru yang masuk kelas tepat waktu akan meningkatkan motivasi dan minat belajar siswa di kelas. Guru harus mematuhi peraturan sekolah yang dibuat kepala sekolah demi mewujudkan pendidikan yang berkualitas, namun masih banyak guru yang belum menyadari pentingnya kedisiplinan. (2) Ada beberapa faktor yang menjadi penghambat kedisiplinan guru dalam melaksanakan kegiatan belajar mengajar yaitu: Faktor Kebijakan Pimpinan, Faktor Kurangnya Kesadaran Diri, Faktor Jarak Tempat Tinggal dengan Sekolah.

\section{Saran}

Dengan ditulisnya makalah ini diharapkan guru menyadari akan pentingnya arti kedisiplinan terhadap pembelajaran yang akan diberikan kepada peserta didik. Dengan dimulainya kedisiplinan pasti akan berimbas pada prestasi peserta didik. Dengan adanya penjelasan tersebut diharapkan dapat memupuk sikap kedisiplinan guru terhadap pembelajaran di kelas sadar akan pentingnya pembelajaran di kelas.

\section{DAFTAR PUSTAKA}

Adelia Vera. 2012. Metode Mengajar Anak di Luar Kelas. Jogjakarta: DIVA Press.

Ahmad Rohani. 2004. Pengelolaan Pengajaran.Jakarta: PT. Asdi Mahasatya

Dimyati dan Mudjiono. 2009. Belajar dan Pembelajaran. Jakarta: PT Rineka

Hasbullah Tabrani. 2004. Rahasia Sukses Belajar. Jakarta: Raja Grafindo Persada

Husamah. 2013. Pembelajaran di Luar Kelas Outdoor Learning. Jakarta: Prestasi Pustaka.

Khadijah. 2013. Belajar dan Pembelajaran. Bandung: Citapustaka Media.

Martinis, Yamin. 2011. Profesionalisasi Guru \& Implementasi KTSP. Jakarta: Gaung Persada Press.

Rusman. 2013. Model-model Pembelajaran, Mengembangkan Profesionalisme Guru. Jakarta: Pt Grafindo Persada

Sondang P. Siagian. 1995. Teori Motivasi dam Aplikasinya. Jakarta: Rineka Cipta.

Sugiyono. 2008. Dasar-Dasar Ilmu Pendidika. Bandung: Alfabeta

Tulus Tu'u. 2004. Peran Disiplin pada Perilaku dan Prestasi Siswa. Jakarta: PT. Raja Grafindo Persada. 